\title{
KONSTRUKSI PETA PAUTAN GENETIK DAN ANALISIS QTL TANAMAN KARET PADA POPULASI HASIL PERSILANGAN ANTARA RRIM 600 DENGAN PN 1546
}

\author{
Construction of Genetic Linkage Map and QTL Analysis of Rubber Plant on the \\ Population of Crossing Result Between RRIM 600 with PN 1546 \\ Sekar WOELAN ${ }^{1 *}$, Chairun NISA $^{2)}$, Tetty CHAIDAMSARI ${ }^{3)}$ dan Edy IRWANSYAH ${ }^{4)}$ \\ ${ }^{1}$ Pusat Penelitian Karet \\ Jalan Salak Nomor 1 Bogor 16151 Jawa Barat \\ Email: sekaryudi@yahoo.com
}

${ }^{2}$ Departemen Agroekoteknologi, Universitas Sumatera Utara

J1. Prof. A. Sofyan No. 3 Kampus USU Medan 20155 Sumatera Utara

${ }^{3} \mathrm{PT}$. Matahari Kahuripan Indonesia

Jl. K. H. Wahid Hasyim 188-190 Jakarta Pusat 10250 DKI Jakarta

${ }^{4}$ GAPKINDO Cabang Sumatera Utara

Kompleks Taman Elok, Blok 1 No. 41/156. Jl. Jendral Gatot Subroto

Sei Sikambing-Medan Sumatera Utara

Diterima : 14 Juli 2016 / Direvisi : 18 Agustus 2016 / Disetujui : 23 September 2016

\begin{abstract}
The availability of genetic linkage maps is one of the conditions in the identification of QTL. Construction of genetic linkage maps could be done on the first derivative of a crossing for open pollinated plants using pseudo-testcross strategy. The objective of this research was to map of QTL position of rubber yield components (girth, bark thickness, number of latex vessel, rubber particle) having high direct effect to yield using a single marker analysis. RAPD genetic linkage maps of rubber plant $(2 n=36)$ was formed by the data markers with pseudotestcross strategy. Populations from crossing between RRIM 600 clone and PN 1546 germplasm were used as genetic material for research of QTL mapping of rubber yield component. The results showed that, at female parent (RRIM 600) could be obtained three linkage groups developed at LOD 3.0, and five linkage groups which were developed by LOD 2.0. While of the male parent (PN 1546) two linkage groups had been obtain which were developed at LOD 2.0. Marker of OPH19_650 on linkage group 2 (LG-2) and OPB2O_1650 on linkage group 3 (LG-3) were predicted to be linked with rubber yield and girth. Marker of OPC13_2000 on linkage group 2 (LG-2) and OPB20_1650 on linkage group 3 (LG-3) were
\end{abstract}

suspected to be linked to latex yield and bark thickness. Markers of OPC13_2000 and OPHO6_850 on linkage group 2 (LG-2) were thought to be related to rubber yield and the number oflatex vessels.

Keywords: Genetic linkage map; RAPD; QTL; first progenies; rubber plant

\begin{abstract}
Abstrak
Tersedianya peta pautan genetik merupakan salah satu syarat dalam identifikasi QTL. Konstruksi peta pautan genetik dapat dilakukan pada tanaman turunan pertama dari suatu persilangan untuk tanaman-tanaman yang menyerbuk bebas dengan menggunakan strategi pseudo-testcross. Tujuan penelitian ini adalah untuk memetakan posisi QTL komponen produksi karet (lilit batang, tebal kulit, jumlah pembuluh lateks, partikel karet) yang mempunyai pengaruh langsung paling besar dengan produksi karet menggunakan analisis marka tunggal. Peta pautan genetik RAPD tanaman karet $(2 n=36)$ dibuat menggunakan data marka dengan strategi pseudo-testcross. Populasi hasil persilangan antara klon RRIM 600 dan plasma nutfah PN 1546 digunakan sebagai
\end{abstract}


materi genetik untuk penelitian pemetaan QTL komponen produksi karet. Hasil penelitian menunjukkan bahwa, pada tetua betina (RRIM 600) telah diperoleh tiga kelompok pautan yang dikonstruksi pada LOD 3,0 dan lima kelompok pautan yang dikonstruksi pada LOD 2,0. Sedangkan pada tetua jantan (PN 1546) telah diperoleh dua kelompok pautan yang dikonstruksi pada LOD 2,0. Marka OPH19_650 pada kelompok pautan 2 (KP-2) dan OPB20_1650 pada kelompok pautan 3 (KP-3) diduga terkait dengan sifat produksi karet dan lilit batang. Marka OPC13_2000 pada kelompok pautan 2 (KP-2) dan OPB20_1650 pada kelompok pautan 3 (KP-3) diduga terkait dengan sifat produksi karet dan tebal kulit. Marka OPC13_2000 dan OPH06_850 pada kelompok pautan 2 (KP-2) diduga terkait dengan sifat produksi karet dan jumlah pembuluh lateks.

Kata kunci: Peta pautan genetik; RAPD; QTL; turunan pertama; tanaman karet

\section{PENDAHULUAN}

Keragaman dari suatu populasi tanaman dapat dikaji melalui penampilan morfologi pada setiap individu yang dapat diamati secara langsung di lapangan. Suatu fenotipe atau morfologi tanaman sangat dipengaruhi oleh faktor genetik dan lingkungan tempat tanaman tumbuh (Hadi, 2003; Aidi-Daslin \& Sayurandi, 2006). Produktivitas adalah sifat kuantitatif yang dikendalikan secara poligenik, sehingga keragaannya sangat dipengaruhi oleh faktor lingkungan. Penelitian mengenai genetika tanaman karet baru sedikit dilakukan. Azwar, Aidi-Daslin, Suhendry dan Woelan (2000) menyatakan bahwa, produktivitas tanaman karet hampir 60\% dipengaruhi oleh faktor genetik, sedangkan sisanya $40 \%$ dipengaruhi oleh faktor lingkungan termasuk di dalamnya sistem budidaya.

Tanaman karet termasuk tanaman menyerbuk silang, bersifat heterozygous, mempunyai siklus hidup yang cukup panjang, sehingga pemuliaan tanaman karet memerlukan waktu yang lama. Pemanfaatan Marker Assited Selection (MAS) di dalam program pemuliaan tanaman dapat membantu mempersingkat masa seleksi pada tanaman karet. Proses seleksi dapat dilakukan bila telah tersedia peta pautan genetik yang berkaitan dengan produksi, yaitu dengan memilih suatu sifat kuantitatif yang terpaut dengan marka molekuler, yang disebut dengan QTL (Quantitative Trait Locus). Adanya asosiasi yang nyata antara sifat dengan marka molekuler menjadi bukti bahwa posisi QTL berada di dekat marka.

Peta pautan yang telah dilakukan pada tanaman karet yaitu dengan menggunakan teknik Isozyme, minisatellites, RFLPs (Restriction Fragment Lenght Polymorphisme), dan AFLP (Amplified Fragment Lenght Polymorphisme) (Lespinasse et al., 2000). Peta pautan genetik karet dengan menggunakan RFLP dilaporkan oleh Seguin, Besse, Lebrun, dan Chevalir (1995), dan dengan menggunakan marka Simple Sequence Repeats (SSR atau mikrosatelit) dilaporkan oleh Seguin, RodierGoud, dan Lespinase (1997). Secara luas konstruksi peta pautan untuk mengidentifikasi sifat-sifat penting banyak disusun dari marka-marka DNA, seperti marka RAPD yang diperkenalkan oleh William, Kubelik, Lirak, Rafalsky, dan Tingey (1990). Novalina (2009) telah mengkonstruksi peta pautan genetik tanaman karet dengan menggunakan marka RAPD.

Peta pautan genetik tanaman karet dapat dibangun pada populasi turunan pertama, karena tetuanya bersifat heterozygote sehingga dianggap menyerupai konfigurasi backcross atau pembentukan F2 murni. Pemetaan genetik pada tanaman karet dapat dilakukan melalui strategi Double Pseudo-Tescross (Grattapaglia \& Sederoff, 1994), yaitu satu tetua berlaku sebagai tetua uji bagi tetua lainnya.

Berdasarkan uraian di atas, maka diperlukan suatu pengkajian terhadap pembentukan peta pautan dari hasil persilangan interspesifik klon RRIM 600 dengan PN 1546. Pada penelitian menggunakan 25 projeni (tanaman $F 1$ ) hasil persilangan dan dua induk persilangan. Digunakan kedua induk tersebut karena klon RRIM 600 sebagai induk betina mempunyai produksi tinggi dan klon PN 1546 sebagai induk jantan mempunyai produksi kayu tinggi namun produksi lateks rendah. Secara genetik kedua klon tersebut mempunyai jarak genetik yang cukup jauh (Woelan, 2013). 
Tujuan dari penelitian ini yaitu mendapatkan peta pautan genetik tanaman karet dari satu set tetua betina RRIM 600 dan satu set dari tetua jantan PN 1546.

\section{BAHAN DAN METODE}

Penelitian telah dilakukan di Kebun Percobaan Balai Penelitian Sungei Putih, Pusat Penelitian Karet dan Laboratorium Bioteknologi, Balai Penelitian Bioteknologi Perkebunan Bogor Indonesia. DNA diisolasi dari daun contoh yang masih stadia muda yang berwarna hijau kekuningan, masih lunak dan terletak pada payung pertama pada posisi paling atas serta pertumbuhan cukup mendapatkan sinar matahari. Pengambilan sampel dilakukan pada pagi hari. Tanaman F1 hasil persilangan RRIM 600 dengan PN 1546 yang ditanam dengan jarak 5 x 4 m di Kebun Percobaan Sungei Putih pada tahun 2008. Sampel daun dimasukkan ke dalam plastik dan diberi label dengan nomor masing-masing projeni yang diuji, hasil segregasi (turunan) dari hasil persilangan RRIM 600 dengan PN 1546. Daun contoh kemudian disimpan dalam termos yang berisi es untuk menjaga kesegaran. Setelah itu daun contoh dibawa ke Balai Penelitian Bioteknologi Perkebunan Bogor Indonesia kemudian disimpan dalam lemari pendingin pada suhu $-20^{\circ} \mathrm{C}$ dan siap untuk diproses ke tahap selanjutnya.

\section{Ekstrasi dan Amplifikasi DNA}

Isolasi DNA dari daun muda tanaman karet dilakukan dengan metode Khanuja, Shasany, Darokat, dan Kumar (1999). Penetapan kuantitas DNA dilakukan dengan mengukur absorbansi larutan DNA menggunakan spektrofotometer sinar UV pada panjang gelombang $260 \mathrm{~nm}$. Nilai 260 (a) $=1$, setara dengan konsentrasi DNA 50 $\mathrm{g} / \mathrm{mL}$. Sedangkan kualitas DNA ditetapkan berdasarkan rasio absorbansi pada panjang gelombang $260 \mathrm{~nm}$ dan $280 \mathrm{~nm}$ serta dengan elektroforesis pada gel agarosa. Amplifikasi DNA dan analisis RAPD dilakukan menggunakan metode Williams et al. (1990). Pada penelitian ini digunakan 100 primer acak dengan ulangan dua kali (duplo) (Tabel $1)$.

\section{Pemilihan Marka RAPD}

Marka RAPD yang diperoleh dari analisis RAPD dengan menggunakan 100 primer acak dekamer (Tabel 1), dipilih yang bersegregasi 1:1. Lokus-lokus yang dipilih untuk pemetaan RRIM 600 (tetua betina) adalah yang muncul pada RRIM 600 tetapi tidak muncul pada PN 1546 (tetua jantan) dan bersegregasi 1:1 pada tanaman turunan. Menurut konfigurasi pseudotestcross, marka-marka yang muncul pada RRIM 600 dan tidak muncul pada PN 1546 diharapkan bersegregasi dengan nisbah 1:1

Tabel 1. Jenis primer RAPD yang digunakan pada penelitian

Table 1. The kind of RAPD primers were used in research

\begin{tabular}{ll}
\hline No & \multicolumn{1}{c}{ Primer } \\
\hline 1. & 15 kit-A (OPA $1,2,3,4,8,10,11,12,13,14,15,17,18,19,20)$ \\
2. & 5 kit-B (OPB 4, 11, 17, 19, 20) \\
3. & 11 kit-C (OPC 2, 3, 5, 7, 8, 9, 12, 13, 14, 19, 20) \\
4. & 13 kit-D (OPD 1, 2, 3, 4, 5, 7, 8, 10, 11, 14, 15, 18, 20) \\
5. & 7 kit-M (OPM 5, 7, 8, 9, 12, 10, 20) \\
6. & 7 kit-N (OPN 3, 5, 9, 10, 15, 16,18) \\
7. & 2 kit-Y (OPY 9, 14) \\
8. & 20 kit-J (OPJ 1, 2, 3, 4, 5, 6, 7, 8, 9, 10, 11, 12, 13, 14, 15, 16, 17, 18, 19, 20) \\
9. & 20 kit-H (OPH 1, 2, 3, 4, 5, 6, 7, 8, 9, 10, 11, 12, 13, 14, 15, 16, 17, 18, 19, 20). \\
10. & 5 kit-B (OPB 4, 11, 17, 19, 20) \\
\hline
\end{tabular}


pada projeni turunan pertama. Hipotesis segregasi 1:1 dari seluruh marka RAPD diuji dengan Chi kuadrat $\left(\mathrm{x}^{2}\right)$.

\section{Konstruksi Peta Pautan Genetika Antar Lokus DNA}

Pembentukan peta pautan genetik antar lokus DNA dilakukan setelah diperoleh data DNA lengkap. Informasi data yang digunakan untuk pembentukan peta pautan bersumber dari hasil segregasi fenotipik dan hasil segregasi lokus-lokus DNA. Peta pautan genetik disusun dengan menggunakan MAPMAKER/EXP 33,1b (Lander et al., 1987). Pautan antara dua marka akan diputuskan jika nilai LOD ( $L o g$ of the Odd) lebih tinggi dari 3,0 dengan frekuensi rekombinasi maksimum 0,25. Jarak genetik dalam centimorgan diduga dengan fungsi pemetaan Haldane (Haldane, 1919). Pada pseudo-testcross setiap tetua menjadi tester satu sama lain, sehingga baik tetua betina (RRIM 600) maupun tetua jantan (PN 1546) akan mempunyai peta pautan antar marka sendiri.

Analisis QTL dapat dilakukan dengan analisis marka tunggal (Single Point Analysis/SPA). Bila susunan marka pada peta pautan belum diperoleh, analisis dapat dilakukan dengan menggunakan marka tunggal (Liu, 1998; Prasetiyono et al., 2003). Metode ini dilakukan dengan cara membagi populasi ke dalam kelas-kelas berdasarkan genotipe setiap lokus atau marka dan menganggap adanya satu QTL jika terdapat perbedaan nyata dalam rataan skor fenotipe untuk masing-masing kelompok. Menurut McCouch dan Doerge (1995) serta Liu (1998), analisis marka tunggal dapat menggunakan uji t-student. Marka terpaut dengan QTL bila nilai peluangnya kurang dari 0,05 atau 0,01.

\section{Verifikasi Lokus Gen Penentu Komponen Produksi Lateks}

Sasaran verifikasi adalah untuk mendapatkan informasi tentang lokus mayor DNA (marka yang konsisten merepresentasikan komponen minor tinggi pada level tertentu). Verifikasi dilakukan dengan menggunakan prosedur bulk segregant analysis (Moretzsohn, Nunes, Ferreira, \& Grattapaglia, 2000).

\section{HASIL DAN PEMBAHASAN}

\section{Peta Pautan}

Berdasarkan hasil keseluruhan reaksi amplifikasi PCR menggunakan 100 primer $\mathrm{RAPD}(\mathrm{OPA}=15, \mathrm{OPB}=5, \mathrm{OPC}=11$, $\mathrm{OPD}=13, \mathrm{OPM}=7, \mathrm{OPN}=7, \mathrm{OPY}=2, \mathrm{OPJ}=$ 20 , dan $\mathrm{OPH}=20$ ) diperoleh 4917 pita yang terdiri dari 190 pita polimorfisme pada tetua betina yang dihasilkan dari 76 primer dan 186 pita polimorfisme pada tetua jantan yang dihasilkan dari 70 primer. Pita monomorfisme yang diperoleh sebanyak 4727 pita (tetua betina) yang dihasilkan dari 24 primer dan 4737 pita (tetua jantan) yang dihasilkan dari 30 primer. Primer polimorfis pada tetua betina menghasilkan 1 - 6 lokus dengan ukuran 250 - 3000 bp. Primer polimorfis pada tetua jantan menghasilkan 1 - 6 lokus dengan ukuran 300-5000 bp.

Dari pemilahan lokus-lokus polimorfisme berdasarkan kriteria pemetaan, diperoleh 190 lokus untuk konstruksi peta pautan pada tetua betina dan 179 lokus untuk konstruksi peta pautan pada tetua jantan. Dari lokus-lokus tersebut, dipilih lokus-lokus yang mempunyai rasio $1: 1$ berdasarkan hasil uji chi kuadrat $(\mathrm{P}>0,05)$, dan diperoleh 40 lokus untuk konstruksi peta pautan pada tetua betina serta 19 lokus untuk konstruksi peta pautan pada tetua jantan.

Peta pautan pada tetua jantan PN 1546 dikonstruksi menggunakan nilai minimum LOD 2,00 dan fraksi rekombinasi maksimum 0,25. Tidak semua lokus dapat dipetakan. Dari 19 lokus terpilih, hanya 4 lokus terpaut, membentuk $2 \mathrm{KP}$ (Kelompok Pautan) dan mencakup 51,0 cM (Tabel 2) sedangkan 15 lokus sisanya tidak dapat dipetakan. Hasil pengamatan jumlah lokus pada setiap KP, masing-masing ditemukan 2 lokus baik pada KP-1 maupun KP-2. Jarak genetik antara dua lokus terpaut tersebut baik pada KP-1 maupun pada KP-2, minimum 25,5 cM dan maksimal 25,5 cM; dengan rata-rata $25,5 \mathrm{cM}$. Pengelompokan pada peta pautan 1 (KP-1) meliputi lokus OPH11_900 dan OPH16_900, sedangkan pada peta pautan 2 (KP-2) meliputi lokus OPJ7_850 dan OPJ11_1200 seperti yang disajikan pada Gambar 1. Sementara Novalina (2009) hanya dapat 
Tabel 2. Karakteristik peta pautan genetik tetua jantan (PN 1546) yang dikonstruksi dengan nilai LOD minimum 2,00 dan fraksi rekombinasi maksimum 0,25

Table 2. The characteristic of linkage map of male parent (PN 1546) which developed by minimum $L O D$ value 2.00 and maximum recombination fraction 0.25

\begin{tabular}{|c|c|c|c|c|c|}
\hline \multirow{2}{*}{$\begin{array}{c}\text { Kelompok } \\
\text { pautan } \\
\text { Linkage group }\end{array}$} & \multirow{2}{*}{$\begin{array}{c}\text { Jumlah } \\
\text { lokus } \\
\text { Number of locus }\end{array}$} & \multirow{2}{*}{$\begin{array}{l}\text { Panjang } \\
\text { Lenght } \\
\text { (cM) }\end{array}$} & \multicolumn{3}{|c|}{$\begin{array}{l}\text { Jarak genetik } \\
\text { Genetic distance } \\
\text { (cM) }\end{array}$} \\
\hline & & & $\begin{array}{l}\text { Minimum } \\
\text { Minimum }\end{array}$ & $\begin{array}{l}\text { Maksimum } \\
\text { Maximum }\end{array}$ & $\begin{array}{l}\text { Rata-rata } \\
\text { Average }\end{array}$ \\
\hline 1 & 2 & 25,5 & 25,5 & 25,5 & 25,5 \\
\hline 2 & 2 & 25,5 & 25,5 & 25,5 & 25,5 \\
\hline Total & 4 & 51,0 & - & - & - \\
\hline Rata-rata & 2 & 25,5 & $25,5^{a}$ & $25,5^{b}$ & $25,5^{c}$ \\
\hline \multicolumn{6}{|c|}{$\begin{array}{l}\text { Jarak genetik minimum antara dua lokus terpaut dari seluruh kelompok pautan } \\
\text { Minimum genetic distance between two linked loci of the entire linkage group }\end{array}$} \\
\hline \multicolumn{6}{|c|}{$\begin{array}{l}\text { Jarak genetik maksimum antara dua lokus terpaut dari seluruh kelompok pautan } \\
\text { Maximum genetic distance between two linked loci of the entire linkage group }\end{array}$} \\
\hline
\end{tabular}
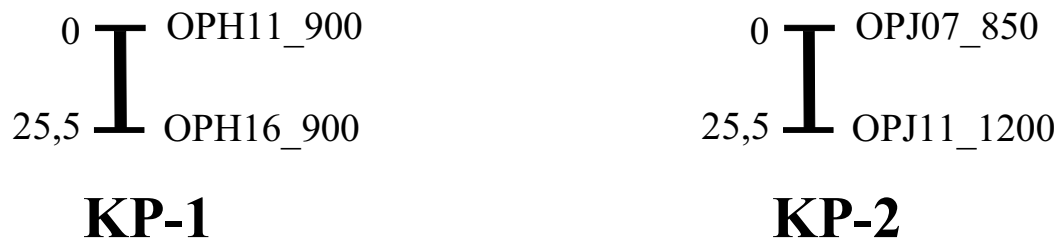

Gambar 1. Peta pautan genetik tetua jantan (PN 1546), dibentuk dengan nilai LOD minimum 2,0 dan fraksi rekombinasi maksimum 0,25.

Figure 1. The genetic linkage map of male parent (PN 1546), developed by minimum LOD value 2.0 and maximum recombination fraction 0.25 .

mengkonstruksi satu kelompok peta pautan pada tetua jantan (PN 711) dengan nilai LOD minimum 1,5.

Peta pautan pada tetua betina RRIM 600 dikonstruksi menggunakan nilai LOD minimum 3,00 dan fraksi rekombinasi maksimum 0,25. Tidak semua lokus dapat dipetakan dari 40 lokus terpilih. Hanya 7 lokus terpaut, membentuk $3 \mathrm{KP}$ dan mencakup 54,8 cM (Tabel 3), sedangkan 33 lokus sisanya tidak dapat dipetakan. Dari hasil pengamatan jumlah lokus pada setiap $\mathrm{KP}$, ditemukan paling sedikit 2 lokus yaitu pada KP-2 dan KP-3 dan paling banyak 3 lokus pada KP-1 dengan rata-rata 2,3 lokus. Sedangkan jarak genetik antara dua lokus terpaut, minimum $(13,7 \mathrm{cM})$ terdapat pada KP-1, KP-2 dan KP-3; maksimal (13,7 cM) terdapat pada KP-1, KP-2 dan KP-3; dengan rata-rata $13,7 \mathrm{cM}$. Pengelompokan peta pautan 1 (KP-1) meliputi lokus OPC2_500, OPD15_2000, dan OPN 15_1650, peta pautan 2 (KP-2) meliputi lokus OPD3_4000 dan OPD11_2000 dan peta pautan 3 (KP-3) meliputi lokus OPD5_1650 dan OPN5_850 (Gambar 2).

Peta pautan tetua betina (RRIM 600) dikonstruksi menggunakan nilai LOD minimum 2,00 dan fraksi rekombinasi maksimum 0,25. Tidak semua lokus dapat dipetakan, dari 40 lokus terpilih, diperoleh 25 lokus terpaut, membentuk $5 \mathrm{KP}$ dan 
Tabel 3. Karakteristik peta pautan tetua betina (RRIM 600) yang dikonstruksi dengan nilai LOD minimum 3,00 dan fraksi rekombinasi maksimum 0,25.

Table 3. The characteristic of linkage map of female parent (RRIM 600) which developed by minimum $L O D$ value 3.00 and maximum recombination fraction 0.25 .

\begin{tabular}{cccccc}
\hline \multirow{2}{*}{$\begin{array}{c}\text { Kelompok } \\
\text { pautan }\end{array}$} & $\begin{array}{c}\text { Jumlah } \\
\text { lokus }\end{array}$ & $\begin{array}{c}\text { Panjang } \\
\text { Lenght } \\
\text { Linkage group }\end{array}$ & Number of locus & $(\mathrm{cM})$ & \multicolumn{3}{c}{$\begin{array}{c}\text { Jarak genetik } \\
\text { Genetic distance } \\
(\mathrm{cM})\end{array}$} \\
\cline { 4 - 6 } & & & $\begin{array}{c}\text { Minimum } \\
\text { Minimum }\end{array}$ & $\begin{array}{c}\text { Maksimum } \\
\text { Maximum }\end{array}$ & $\begin{array}{c}\text { Rata-rata } \\
\text { Average }\end{array}$ \\
\hline 1 & 3 & 27,4 & 13,7 & 13,7 & 13,7 \\
2 & 2 & 13,7 & 13,7 & 13,7 & 13,7 \\
3 & 2 & 13,7 & 13,7 & 13,7 & 13,7 \\
Total & 7 & 54,8 & - & - & - \\
Rata-rata & 2,3 & 18,3 & $13,7^{\mathrm{a}}$ & $13,7^{\mathrm{b}}$ & $13,7^{\mathrm{c}}$ \\
\hline
\end{tabular}

a Jarak genetik minimum antara dua lokus terpaut dari seluruh kelompok pautan

Minimum genetic distance between two linked loci of the entire linkage group

${ }^{\mathrm{b}}$ Jarak genetik maksimum antara dua lokus terpaut dari seluruh kelompok pautan

Maximum genetic distance between two linked loci of the linkage group

' Jarak genetik rata-rata antara dua lokus terpaut dari seluruh kelompok pautan

Average of genetic distance between two linked loci of the entire linkage group

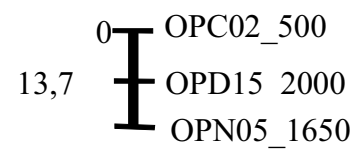

KP-1
${ }_{13,7}^{0} \mathbf{I}_{\text {OPD11_2000 }}^{\text {OPD03_4000 }}$

KP-2
${ }_{13,7}{ }^{0} \boldsymbol{工}_{\text {OPN05_850 }}^{\text {OPD05 } 1650}$

KP-3

Gambar 2. Peta pautan genetik tetua betina, dibentuk dengan nilai LOD minimum 3,0 dan fraksi rekombinasi maksimum 0,25.

Figure 2. The genetic linkage map of male parent (PN 1546), developed by minimum LOD value 3.0 and maximum recombination fraction 0.25

mencakup 1495,8 cM (Tabel 4), sedangkan 15 lokus sisanya tidak dapat dipetakan. Dari hasil pengamatan jumlah lokus pada setiap KP, ditemukan paling sedikit 2 lokus yaitu pada KP-1, KP-3, KP-4, dan KP-5; paling banyak 17 lokus yaitu pada KP-2; dengan rata-rata 5 lokus. Sedangkan jarak genetik antara dua lokus terpaut, minimum $(19,3 \mathrm{cM})$ terdapat pada KP-5; maksimal $(345,4 \mathrm{cM})$ terdapat pada KP-2; dengan ratarata $36,66 \mathrm{cM}$ dengan pengelompokan peta pautan 1 (KP-1) meliputi lokus OPB19_4000 dan OPB19_5000; peta pautan 2 (KP-2) meliputi lokus OPB20_750, OPC2_500, OPC13_2000, OPD3_4000, OPD5_1650, OPD11_2000, OPD15_2000, OPH03_900,
OPH06_850, OPH13_5000, OPH15_500, OPH19_650, OPM05_500, OPN05_850, OPNO9_3000, OPN15_850 dan OPN15_1650; peta pautan 3 (KP-3) meliputi lokus OPB20_1650 dan OPD11_500; peta pautan 4 (KP-4) meliputi lokus OPB20_2500 dan OPJ09_800; dan peta pautan 5 (KP-5) meliputi OPD8_3000 dan OPM5_1000 yang disajikan pada Gambar 3

Semua lokus pada 3 kelompok pautan (KP-1, KP-2, KP-3) yang dikonstruksi dengan LOD minimum 3,0, berada pada kelompok pautan 2 (KP-2) setelah dikonstruksi dengan LOD minimum 2,0. 
Tabel 4. Karakteristik peta pautan tetua betina (RRIM 600) yang dikonstruksi dengan nilai LOD minimum 2,00 dan fraksi rekombinasi maksimum 0,25

Table 4. The characteristic of linkage map of female parent (RRIM 600) which developed by minimum LOD value 2.00 and maximum recombination fraction 0.25

\begin{tabular}{|c|c|c|c|c|c|}
\hline \multirow{2}{*}{$\begin{array}{c}\text { Kelompok } \\
\text { pautan } \\
\text { Linkage group }\end{array}$} & \multirow{2}{*}{$\begin{array}{c}\text { Jumlah } \\
\text { lokus } \\
\text { Number of locus }\end{array}$} & \multirow{2}{*}{$\begin{array}{l}\text { Panjang } \\
\text { Lenght } \\
\text { (cM) }\end{array}$} & \multicolumn{3}{|c|}{$\begin{array}{l}\text { Jarak genetik } \\
\text { Genetic distance } \\
\text { (cM) }\end{array}$} \\
\hline & & & $\begin{array}{l}\text { Minimum } \\
\text { Minimum }\end{array}$ & $\begin{array}{l}\text { Maksimum } \\
\text { Maximum }\end{array}$ & $\begin{array}{c}\text { Rata-rata } \\
\text { Average }\end{array}$ \\
\hline 1 & 2 & 25,5 & 25,5 & 25,5 & 25,5 \\
\hline 2 & 17 & 1400,0 & 25,5 & 345,4 & 87,5 \\
\hline 3 & 2 & 25,5 & 25,5 & 25,5 & 25,5 \\
\hline 4 & 2 & 25,5 & 25,5 & 25,5 & 25,5 \\
\hline 5 & 2 & 19,3 & 19,3 & 19,3 & 19,3 \\
\hline Total & 25 & 1495,8 & - & - & - \\
\hline Rata-rata & 5 & 299,16 & $24,26^{a}$ & $88,24^{b}$ & $36,66^{c}$ \\
\hline
\end{tabular}

a Jarak genetik minimum antara dua lokus terpaut dari seluruh kelompok pautan

Minimum genetic distance between two linked loci of the entire group

${ }^{\mathrm{b}}$ Jarak genetik maksimum antara dua lokus terpaut dari seluruh kelompok pautan

Maximum genetic distance between two linked loci of the entire linkage group

' Jarak genetik rata-rata antara dua lokus terpaut dari seluruh kelompok pautan

Average of genetic distance between two linked loci of the entire linkage group

Hasil penelitian Novalina (2009) menyimpulkan bahwa peta pautan PB 260 yang dikonstruksi dengan LOD minimum 3,0 hanya menghasilkan satu kelompok peta pautan pada masing-masing populasi (A, B, dan gabungan). Ketidak-sesuaian jumlah pautan genetik yang dihasilkan dengan jumlah kromosom yang dimiliki oleh suatu tanaman, kemungkinan disebabkan oleh jumlah marka yang dihasilkan masih terlalu sedikit untuk mencakup seluruh kromosom, sehingga penggunaan markamarka lainnya perlu dilakukan (Septiningsih, Trijatmiko, Moeljopawiro, \& Mcouch, 2003). Dengan menggunakan beberapa jenis marka, Lespinase et al. (2000) berhasil mengkonstruksi 18 kelompok pautan yang sesuai dengan kromosom karet $2 \mathrm{n}=2 \mathrm{x}=36(\mathrm{n}=\mathrm{x}=18)$ yang dikonstruksi dari 717 lokus yang berasal dari 301 marka RFLP, 388 marka AFLP, 18 marka mikrosatelit dan 10 isozymes. Total jarak genetik $2144 \mathrm{cM}$ dan rata-rata jarak antar marka $3 \mathrm{cM}$.
Banyaknya kelompok pautan yang terbentuk dan jumlah marka yang tergabung dalam suatu kelompok pautan ditentukan oleh penentuan kriteria pengelompokan (Setiyo, 2001). Peta pautan yang terbentuk baik pada tetua jantan maupun tetua betina masih jauh dari ideal, karena hanya 2 kelompok pautan (KP) yang terbentuk pada tetua jantan dengan LOD 2,00 . Sedangkan pada tetua betina dengan LOD 3,00 diperoleh 3 kelompok pautan (KP) dan LOD 2,0 diperoleh 5 kelompok pautan (KP).

\section{QTL Komponen Hasil}

Analisis QTL (Quantitative Trait Loci) dilakukan untuk menentukan eksistensi dan efek genetik dari lokus yang mengendalikan sifat kuantitatif spesifik. Penggunaan marka molekuler yang terpaut dengan karakter tertentu dan posisinya sangat dekat dengan QTL merupakan strategi penting untuk meningkatkan keakuratan seleksi. Hal ini hanya dapat 


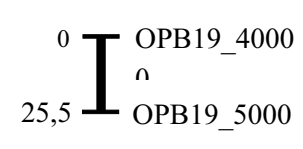

KP-1

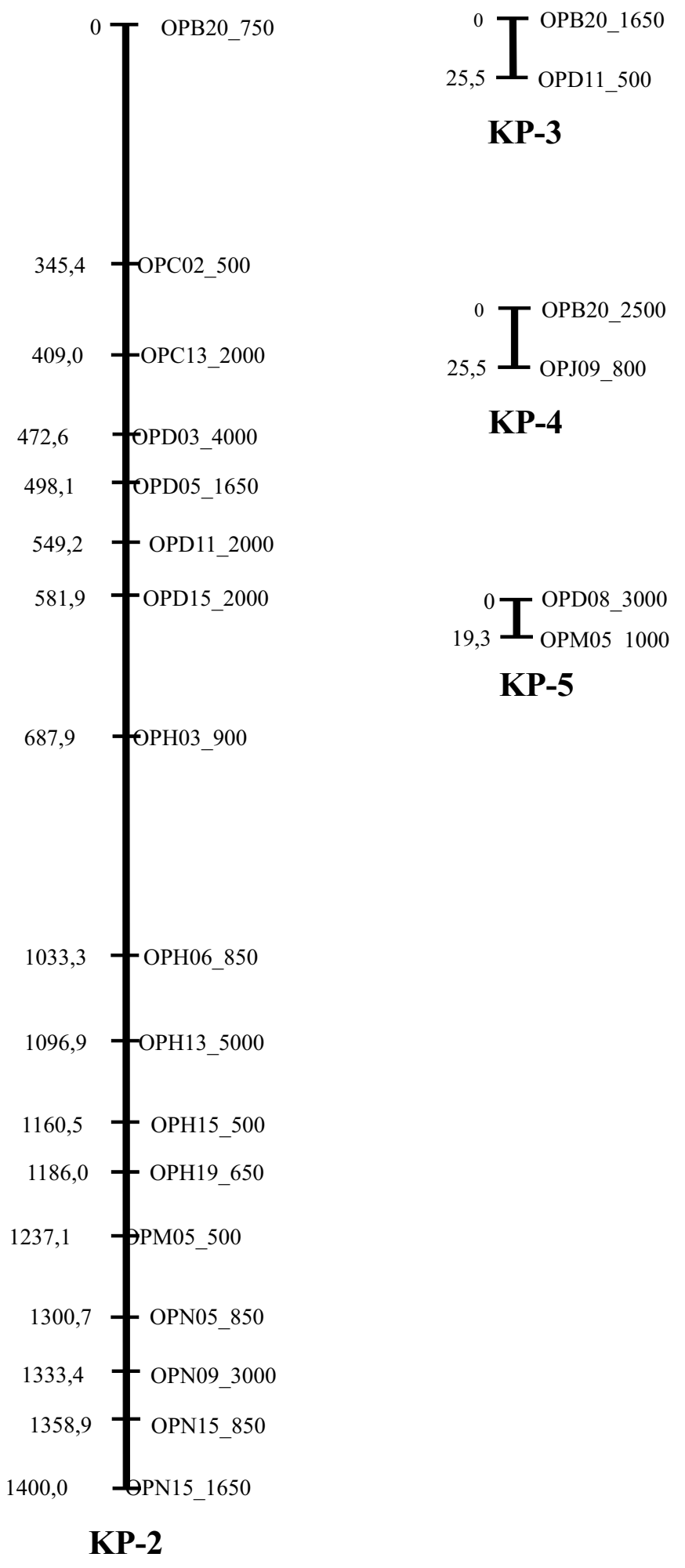

Gambar 3. Peta pautan genetik tetua betina, dibentuk dengan nilai LOD minimum 3,0 dan fraksi rekombinasi maksimum 0,25.

Figure 3. The genetic linkage map of male parent (PN 1546), developed by minimum LOD value 3.0 and maximum recombination fraction 0.25 
dilakukan apabila peta pautan yang terbentuk mempunyai kerapatan yang tinggi. Kerapatan tinggi hanya dapat dibentuk dengan cara memperbanyak skrining primer RAPD, meningkatkan ukuran populasi, serta kemungkinan menggabungkan data marka RAPD dengan marka jenis lainnya.

Berdasarkan hasil pengamatan data kuantitatif komponen hasil dan hasil lateks pada populasi hasil RRIM 600 dengan PN 1546 (Bc1), diketahui adanya peristiwa hambatan pautan yang masih besar. Harapan untuk mendapatkan progeni BC1 yang mempunyai produksi lateks dan kayu tinggi belum diperoleh. Selain besarnya hambatan pautan, konsekuensi lain dari program silang balik adalah waktu yang diperlukan cukup lama. Hasil penelitian Irwansyah (2004) pada tanaman sawit, menyatakan bahwa konstruksi peta pautan suatu tanaman awalnya tidak langsung mendapatkan peta berkerapatan tinggi dan jumlah kelompok pautannya sesuai kromosom haploidnya. Kelompok pautan yang diperoleh pada umumnya lebih besar atau lebih kecil dari kromosom haploidnya.

Berdasarkan hasil analisis sidik lintasan pada penelitian sebelumnya (Woelan, 2013; Woelan et al., 2014) diketahui bahwa empat peubah komponen produksi lateks yang mempunyai pengaruh paling besar terhadap produksi lateks yaitu lilit batang, tebal kulit, jumlah pembuluh lateks, dan jumlah partikel karet. Selanjutnya, dari hasil identifikasi QTL pada komponen produksi lateks diharapkan adanya marka QTL sebagai kriteria seleksi (tidak langsung) untuk memilih progeni yang memiliki produksi lateks tinggi.

Pada penelitian ini analisis QTL dilakukan menggunakan analisis marka tunggal dengan menggunakan uji t-student. Hal ini dilakukan karena jumlah peta pautan yang diperoleh belum sesuai dengan jumlah kromosom tanaman karet $2 \mathrm{n}=2 \mathrm{x}=$ $36(\mathrm{n}=\mathrm{x}=18)$.

Hasil analisis marka tunggal melalui uji $t$ terhadap marka RAPD yang bersegregasi $1: 1$ pada populasi RRIM 600 dan PN 1546 disajikan pada Tabel 5 . Berdasarkan hasil uji $t$ diperoleh beberapa marka yaitu OPB20_1650, OPC13_2000, OPH03_650, OPH03_2000, OPH06_850,
OPH12_500, OPH19_650, OPJ15_4000, OPJ16_1400, dan OPJ19_650. Sepuluh marka tersebut merupakan marka yang muncul pada tetua betina (RRIM 600) tetapi tidak muncul pada tetua jantan sehingga diduga bahwa terdapat QTL yang terkait dengan sifat produksi lateks yang berada dekat lokus OPB20_1650, OPC13_2000, OPH03_650, OPH03_2000, OPH06_850, OPH12-500, OPH19_650, OPJ15_4000, OPJ16_1400, dan OPJ19_650. Peubahpeubah yang telah diketahui sebelumnya berkorelasi secara nyata juga dilakukan uji $t$ untuk mengetahui keterpautannya dengan OPB20_1650, OPC13_2000, OPH03_650, OPH03_2000, OPH06_850, OPH12_500, OPH19_650, OPJ15_4000, OPJ16_1400, dan OPJ19_650.

Hasil uji $t$ untuk mendeteksi segregasi bersama antara 10 lokus (OPB20_1650, OPC13_2000, OPH03_650, OPH03_2000, OPH06_850, OPH12_500, OPH19_650, OPJ15_4000, OPJ16_1400, dan OPJ19_650) dengan sifat lilit batang, tebal kulit, jumlah pembuluh lateks, dan jumlah partikel karet disajikan pada Tabel 6.

Berdasarkan hasil uji $t$ diketahui bahwa nilai tengah untuk sifat lilit batang antara tanaman-tanaman yang mempunyai fragmen OPB20_1650, OPC13_2000, OPH12_500, OPH19_650, dan OPJ15_4000 (alel 1) dengan tanaman-tanaman yang tidak mempunyai fragmen OPB20_1650, OPC13_2000, OPH12_500, OPH19_650,dan OPJ15_4000 berbeda secara nyata. Diduga bahwa marka yang terpaut dengan sifat produksi yang tinggi karena keterkaitan marka OPB20_1650, OPC13_2000, OPH12_500, OPH19_650, dan OPJ15_4000 tersebut dengan sifat lilit batang.

Nilai tengah untuk sifat tebal kulit antara tanaman-tanaman yang mempunyai fragmen OPB20_1650, OPH06_850, OPH12_500, OPJ15_4000, OPJ16_1400 dan OPJ19_650 (alel 1) dengan tanamantanaman yang tidak mempunyai fragmen OPB20_1650, OPH06_850, OPH12_500, OPJ15_4000, OPJ16_1400 dan OPJ19_650 berbeda secara nyata. Diduga PP bahwa marka OPB20_1650, OPHO6_850, OPH12_500, OPJ15_4000, OPJ16_1400 dan OPJ19_650 yang terpaut dengan sifat produksi yang tinggi karena keterkaitan marka tersebut dengan tebal kulit. 
Tabel 5. Nilai rata-rata produksi lateks $(\mathrm{g} / \mathrm{p} / \mathrm{s})$ pada masing-masing marka RAPD berdasarkan muncul atau tidaknya fragmen DNA pada masing-masing marka tersebut serta hasil uji $t$ pada populasi

Table 5. The average value of latex yield $(\mathrm{g} / \mathrm{t} / \mathrm{t})$ on each RAPD markers based on emerging orabsence of markers and the result of $\mathrm{t}$ test in the population

\begin{tabular}{|c|c|c|c|c|}
\hline \multirow[t]{2}{*}{$\begin{array}{l}\text { Marka RAPD } \\
\text { RAPD markers }\end{array}$} & \multicolumn{2}{|c|}{$\begin{array}{c}\text { Nilai tengah } \\
\text { Produksi pada alel } \\
\text { The mean of yield on allel }\end{array}$} & \multirow[t]{2}{*}{$\begin{array}{l}\text { Beda nilai tengah } \\
\text { The median value different }\end{array}$} & \multirow[t]{2}{*}{$\begin{array}{l}t \text { hitung } \\
t \text { test }\end{array}$} \\
\hline & 1 & 0 & & \\
\hline OPA02_500 & 4,346 & 4,850 & $-0,504$ & $-0,841$ \\
\hline OPA04_850 & 4,050 & 5,027 & $-0,978$ & $-1,573$ \\
\hline OPA10_2000 & 3,691 & 5,380 & $-1,690$ & $-2,449$ \\
\hline OPB19_4000 & 4,464 & 4,766 & $-0,302$ & $-0,501$ \\
\hline OPB19_5000 & 3,211 & 4,412 & $-1,201$ & $-1,572$ \\
\hline OPB20_750 & 3,797 & 5,146 & $-1,349$ & $-2,234$ \\
\hline OPB20_1650 & 5,176 & 3,790 & 1,387 & 2,317 \\
\hline OPB20_2500 & 4,256 & 4,965 & $-0,709$ & $-1,158$ \\
\hline OPCO2_500 & 4,772 & 4,561 & 0,211 & 0,325 \\
\hline OPC13_2000 & 5,395 & 4,260 & 1,135 & 1,709 \\
\hline OPD03_4000 & 3,139 & 5,391 & $-2,251$ & $-0,841$ \\
\hline OPD05_1650 & 3,229 & 5,221 & $-1,992$ & $-3,061$ \\
\hline OPD08_3000 & 4,365 & 4,837 & $-0,472$ & $-0,790$ \\
\hline OPD11_500 & 4,557 & 4,709 & $-0,153$ & $-0,258$ \\
\hline OPD11_2000 & 3,339 & 5,232 & $-1,893$ & $-2,637$ \\
\hline OPD15_2000 & 4,098 & 4,653 & $-0,555$ & $-1,187$ \\
\hline OPH03_650 & 4,924 & 4,061 & 0,863 & 2,163 \\
\hline OPH03_900 & 4,435 & 4,743 & $-0,309$ & $-0,480$ \\
\hline OPH03_2000 & 5,507 & 3,989 & 1,517 & 1,970 \\
\hline OPH06_850 & 6,303 & 3,643 & 2,660 & 4,519 \\
\hline OPH09_600 & 3,205 & 5,073 & $-1,868$ & $-2,239$ \\
\hline OPH12_500 & 5,463 & 3,845 & 1,618 & 2,728 \\
\hline OPH13_5000 & 5,182 & 4,369 & 0,812 & 1,196 \\
\hline OPH15_500 & 4,936 & 4,463 & 0,474 & 0,748 \\
\hline OPH19_650 & 6,244 & 3,816 & 2,428 & 3,848 \\
\hline OPH19_1000 & 4,864 & 4,451 & 0,413 & 0,683 \\
\hline OPJ1_850 & 4,132 & 4,895 & $-0,763$ & $-1,197$ \\
\hline OPJ9_800 & 4,982 & 4,298 & 0,684 & 1,159 \\
\hline OPJ9_1400 & 3,565 & 5,285 & $-1,720$ & $-2,731$ \\
\hline PJ15_700 & 4,277 & 4,922 & $-0,646$ & $-1,009$ \\
\hline OPJ15_4000 & 5,577 & 4,173 & 1,404 & 2,128 \\
\hline OPJ16_1400 & 4,317 & 4,220 & 0,097 & 2,161 \\
\hline OPJ19_650 & 5,262 & 3,950 & 1,312 & 3,070 \\
\hline OPM5_500 & 4,898 & 4,486 & 0,412 & 0,673 \\
\hline OPM5_1000 & 3,964 & 4,763 & $-0,799$ & $-0,575$ \\
\hline OPN5_850 & 4,132 & 4,895 & $-0,763$ & $-1,197$ \\
\hline OPN9_3000 & 3,071 & 5,425 & $-2,355$ & $-3,899$ \\
\hline OPN15_850 & 4,965 & 4,506 & 0,459 & 0,678 \\
\hline OPN15_1650 & 3,590 & 5,165 & $-1,576$ & $-2,526$ \\
\hline OPN16_1000 & 4,670 & 4,607 & 0,062 & 0,106 \\
\hline
\end{tabular}

Keterangan: $t$ tabel $\left(t_{0,05}=1,71 ; t_{0,01}=2,50\right)$

Note $\quad$ : t test 
Tabel 6. Nilai tengah yang diamati pada alel yang berbeda untuk marka RAPD berdasarkan muncul atau tidaknya fragmen DNA pada masing-masing marka serta hasil uji $t$

Table 6. The mean observed in different alleles for RAPD markers by emerging or absence of $D N A$ fragment at each markers and the result of t test

\begin{tabular}{|c|c|c|c|c|}
\hline \multirow{2}{*}{$\begin{array}{c}\text { Sifat kuantitatif } \\
\text { Quantitative characters }\end{array}$} & \multicolumn{2}{|c|}{$\begin{array}{c}\text { Nilai tengah alel } \\
\text { The median value allel }\end{array}$} & \multirow{2}{*}{$\begin{array}{c}\text { Beda nilai tengah } \\
\text { The median value } \\
\text { different }\end{array}$} & \multirow{2}{*}{$\begin{array}{l}t \text { hitung } \\
t \text { test }\end{array}$} \\
\hline & 1 & 0 & & \\
\hline \multicolumn{5}{|c|}{ OPB20_1650 } \\
\hline Lilit batang & 47,400 & 40,540 & 6,860 & 3,061 \\
\hline Tebal kulit & 7,100 & 6,750 & 0,350 & 1,986 \\
\hline \multicolumn{5}{|c|}{ OPC13_2000 } \\
\hline Lilit batang & 47,875 & 43,141 & 4,734 & 1,879 \\
\hline Jumlah pembuluh lateks & 6,313 & 5,588 & 0,724 & 3,190 \\
\hline \multicolumn{5}{|c|}{ OPH03_650 } \\
\hline Jumlah pembuluh lateks & 6,042 & 5,615 & 0,426 & 2,103 \\
\hline \multicolumn{5}{|c|}{ OPH03_2000 } \\
\hline Jumlah partikel karet & 10,000 & 4,976 & 0,676 & 7,434 \\
\hline \multicolumn{5}{|c|}{ OPH06_850 } \\
\hline Tebal kulit & 7,222 & 6,813 & 0,410 & 2,242 \\
\hline Jumlah pembuluh lateks & 6,500 & 5,438 & 1,063 & 5,235 \\
\hline \multicolumn{5}{|c|}{ OPH12_500 } \\
\hline Lilit batang & 47,787 & 39,960 & 7,827 & 3,528 \\
\hline Tebal kulit & 7,400 & 6,400 & 1,000 & 6,206 \\
\hline Jumlah pembuluh lateks & 6,267 & 5,150 & 1,117 & 5,822 \\
\hline \multicolumn{5}{|c|}{ OPH19_650 } \\
\hline Lilit batang & 50,088 & 42,100 & 7,988 & 3,257 \\
\hline Diameter pembuluh lateks & 21,018 & 19,635 & 1,382 & 4,101 \\
\hline \multicolumn{5}{|c|}{ OPJ15-4000 } \\
\hline Lilit batang & 54,963 & 39,806 & 15,157 & 6,999 \\
\hline Tebal kulit & 7,375 & 6,647 & 0,728 & 3,938 \\
\hline \multicolumn{5}{|c|}{ OPJ16_1400 } \\
\hline Tebal kulit & 7,375 & 6,765 & 0,610 & 3,221 \\
\hline \multicolumn{5}{|c|}{ OPJ19_650 } \\
\hline Tebal kulit & 7,300 & 6,733 & 0,567 & 3,292 \\
\hline Jumlah pembuluh lateks & 6,300 & 5,500 & 0,800 & 3,942 \\
\hline
\end{tabular}

Keterangan: $t$ tabel $\left(t_{0,05}=1,71 ; t_{0,01}=2,50\right)$

Note $: t$ table

Nilai tengah untuk sifat jumlah pembuluh lateks antara tanaman-tanaman yang mempunyai fragmen OPC13-2000, OPH03_650, OPH06_850, OPH12_500 dan OPJ19_650 (alel 1) dengan tanamantanaman yang tidak mempunyai fragmen OPC13_2000, OPH03_650, OPH06_850, OPH12_500 dan OPJ19_650 berbeda secara nyata. Diduga bahwa marka OPC13_2000, OPH03_650, OPH06_850, OPH12_500 dan OPJ19_650 yang terpaut dengan sifat produksi yang tinggi karena keterkaitan marka tersebut dengan jumlah pembuluh lateks.
Nilai tengah untuk sifat jumlah partikel karet antara tanaman-tanaman yang mempunyai fragmen OPH03_2000 (alel 1) dengan tanaman-tanaman yang tidak mempunyai fragmen OPH03_2000 berbeda secara nyata. Diduga bahwa marka OPH03_2000 yang terpaut dengan sifat produksi yang tinggi karena keterkaitan marka tersebut dengan jumlah partikel karet.

Dari hasil penelitian ini, posisi QTL yang terdeteksi kemungkinan merupakan lokus-lokus yang terdiri atas banyak alel 
yang mengontrol sifat produksi lateks. Sanjaya et al. (2002) menyatakan bahwa pengembangan peta genetik berkerabatan tinggi yang terdiri atas marka molekuler telah memungkinkan untuk mengidentifikasi lokus-lokus yang mempengaruhi sifat kuantitatif pada berbagai tanaman.

Walaupun analisis marka tunggal mendapatkan 10 marka yang terpaut dengan QTL, tetapi hasil tersebut belum memberikan rincian data mengenai frekuensi rekombinasi di antara markamarka dengan QTL dan juga efek dari QTL. Identifikasi QTL melalui analisis marka tunggal masih mempunyai kelemahan yaitu lokasi tepat QTL tidak dapat diketahui secara pasti, dan dalam hal ini QTL dipetakan berdasarkan perkiraan dari hasil uji $t$ (Tabel 5 dan Tabel 6). Fenomena ini sama dengan hasil penelitian yang dilakukan oleh Novalina (2009) pada tanaman karet dan Prasetiyono et al. (2003) pada tanaman padi.

Namun demikian dari hasil penelitian ini sudah dapat diidentifikasi posisi peta dan karakteristik QTL dari peubah komponen produksi yang mempunyai pengaruh langsung yang tinggi. Lilit batang memiliki tiga QTL, yaitu $l b 2-1$ dan $l b 2-2$ yang posisinya berturut-turut berada pada marka OPC13_2000 (63,6 cM) dan OPH19_650 (51,1 cM), serta $l b 3-1$ yang posisinya berada pada marka OPB20_1650 (25,5 cM). Eksistensi QTL ini dideteksi pada LOD minimum 2,0 dan berada pada KP-2 dan KP-3 (Gambar 3).

Tebal kulit memiliki dua QTL, yaitu tk2-1 yang posisinya berada pada marka OPC13_2000 (63,6 cM) dan tk3-1 yang posisinya berada pada marka OPB20_1650 (25,5 cM). Eksistensi QTL ini dideteksi pada LOD minimum 2,0 dan berada pada KP-2 dan KP-3 (Gambar 3).

Jumlah pembuluh lateks memiliki dua QTL, yaitu jpl2-1, jpl2-2 yang posisinya berada pada lokus OPC13_2000 (63,6 cM) dan OPH06_850 (63,6 cM). Eksistensi QTL ini dideteksi pada LOD minimum 2,0 dan berada pada KP-2 (Gambar 3). Teridentifikasinya QTL jumlah pembuluh lateks dan produksi yang terpaut dengan lokus OPC13_3000 pada KP-2 baik dari hasil penelitian ini maupun hasil penelitian Novalina (2009), mengindikasikan adanya konsistensi keberadaan lokus OPC13-3000 yang terpaut dengan karakter jumlah pembuluh lateks dan produksi lateks. Sedangkan eksistensi QTL jumlah partikel karet dan produksi lateks yang terpaut dengan lokus OPH03_2000, QTL lilit batang dan produksi lateks yang terpaut dengan lokus OPH12_500, OPJ15_4000, serta QTL tebal kulit dan produksi yang terpaut dengan lokus OPH12_500, OPJ15_4000, OPJ16_1400,OPJ19_650, belum dapat dipetakan sampai dengan LOD minimum 2,0. Dari 40 lokus yang terpilih, hanya 25 marka yang terpaut, membentuk lima KP dan mencakup 1495,8 cM.

Konstruksi peta pautan suatu tanaman pada awalnya tidak langsung mendapatkan peta berkerapatan tinggi dan jumlah KP-nya sesuai kromosom haploidnya. KP yang diperoleh umumnya lebih besar atau lebih kecil dari kromosom haploidnya.

\section{KESIMPULAN}

Peta pautan tetua betina RRIM 600 yang dikonstruksi pada nilai LOD minimum 2,0 dengan fraksi rekombinasi maksimum 0,25 dapat dijadikan dasar analisis pautan (QTL) dengan menggunakan uji $t$, walaupun jumlah KP yang dihasilkan hanya lima dan jarak antar dua marka terpaut 36,6 cM. Dua lokus OPC13_2000, OPH19_650 pada KP-2 dan OPB20_1650 pada KP-3 diduga terpaut dengan karakter lilit batang, satu lokus OPC13_2000 pada KP-2 dan satu lokus OPB20_1650 pada KP-3 diduga terpaut dengan tebal kulit, serta dua lokus OPC13_2000 dan OPH06_850 pada KP-2 diduga terpaut dengan jumlah pembuluh lateks. Perbedaan jumlah KP yang diperoleh antara peta pautan tetua betina (5 KP) dengan tetua jantan (2 KP) disebabkan adanya perbedaan heterosigositas (latar belakang genetik) antara keduanya.

Agar diperoleh peta pautan yang ideal yang sesuai dengan jumlah kromosom tanaman karet $2 \mathrm{n}=2 \mathrm{x}=36(\mathrm{n}=\mathrm{x}=18)$ perlu memperbanyak primer RAPD yang diskrining, meningkatkan ukuran populasi serta menggabungkan data marka RAPD dan data marka DNA jenis lain (SSR atau 
mikrosalit, AFLP, RFLP). Semakin banyak marka DNA yang tersedia, diharapkan dapat meningkatkan pengujian polimorfisme DNA yang berguna untuk pemetaan genetik, marka untuk pemuliaan tanaman, dan eksplorasi hubungan kekerabatan.

\section{DAFTAR PUSTAKA}

Aidi-Daslin., \& Sayurandi. (2006). Pengaruh interaksi genotipe dan lingkungan terhadap pertumbuhan dan produksi klon IRR seri 100 pada uji lanjutan. Jurnal Penelitian Karet, 24(2), 91-100.

Azwar, R., Aidi-Daslin., Suhendry, I., \& Woelan, S. (2000). Quantifying genetical and enviromental factors in determining rubber crop productivity. Proceedings Indonesian Rubber Conference and IRRDB Symposium (pp. 143-149). Bogor, Indonesia: IRRIIRRDB.

Grattapaglia, D., \& Sederoff, R. (1994). Genetic linkage maps of Eucalyptus grandis and Eucalyptus urophylla using a pseudo-testcross: mapping strategy and RAPD markers. Genetics, 137(4), 1121-1137.

Hadi, H. (2003). Analisis genetik sifat ketahanan tanaman karet (Hevea brasiliensis Muell Arg.) terhadap penyakit gugur daun Corynespora (Disertasi). Institut Pertanian Bogor, Indonesia.

Haldane, B. J. B. S. (1919). The combination of linkage maps of calculation of distances between the loci of linked factors. Journal Genetics, 8, 299-309.

Irwansyah, E. (2004). Peta pautan genetik marka RAPD, analisis QTL kelapa sawit menggunakan populasi silang balik generasi pertama menuju perbaikan kualitas minyak (Disertasi). Institut Pertanian Bogor, Indonesia.
Khanuja, S. P. S., Shasany, A. K., Darokat, M. P., \& Kumar, S. (1999). Rapid isolation of DNA from dry and fresh samples of plant producing large amounts of secondary metabolism and essential oils. Plant Molecular Biology Re porter, 17 ( 1 ) , 1 - 7 . Doi:10.1023/A:1007528101452.

Lander, E. S., Green, P., Abrahamson, J., Barlow, A., Daly, M. J., Lincoln, S. E., \& Newburg, L. (1987). Mapmaker: an interactive computer package for constructing primary genetic linkage map of experimental and natural population. Genomic, 1(2), 174-181. Doi: 10.1016/0888-7543(87)90010-3.

Lespinasse D., Rodier-Goud, M., Grivet, L., Leconte, A., Legnate, H., \& Seguin, M. (2000). A saturated genetics linkage map of rubber tree (Hevea spp) based on RFLP, AFLP, microsatellite, and isozyme markers. Theoretical and Applied Genetics, 100(1), 127-138. Doi: $10.1007 / \mathrm{s} 001220050018$.

Liu, B. H. (1998). Statistical Genomics: Linkage, Mapping, and QTL Analisis. New York, USA: CRC Press.

McCouch, S. R., \& Doerge, R. W. (1995). QTL Mapping in Rice. Trends Genet, 11(12), $482-487$.

Moretzsohn, M. C., Nunes, C. D. M., Ferreira, M. E., \& Grattapaglia, D. (2000). RAPD linkage mapping of the shell thickness locus in oil palm (Elaeis guineensis Jacq). Theoretical and Applied Genetics, 100(1), 63-70. Doi: $10.1007 / \mathrm{s} 001220050009$.

Novalina. (2009). Deteksi marka genetik yang terpaut dengan komponen produksi lateks pada tanaman karet (Hevea brasiliensis Muell Arg.) melalui pemetaan QTL. (Disertasi). Institut Pertanian Bogor, Indonesia. 
Prasetiyono, J., Tasliah., Aswidinnoor, H., \& Moeljopawiro, S. (2003). Identifikasi marka mikrosatelit yang terpaut dengan sifat toleransi terhadap kerancuan aluminium pada padi persilangan Dupa x ITA 131. Jurnal Bioteknologi Pertanian, 8(2), 35-45.

Sanjaya, L., Wattimena, G. A., Guharja, E., Yusuf, M., Aswidinnoor, H., \& Stam, P. (2002). Pemetaan QTL untuk sifat ketahanan terhadap penyakit antraknose pada Capsicum spp. Jurnal Bioteknologi Pertanian, 2, 43-54.

Septiningsih, E. M., Trijatmiko, K. R., Moeljopawiro, S., \& Mcouch, S. R. (2003). Identification of quantitative trait loci for grain quality in an advanced backcross population derived from the Oryza sativa variety IR64 and the wild relative O. rufipogon. Theory Applied Genetics, 107(8), 1433-1441. Doi: 10.1007/s00122003-1376-z.

Sequin, M., Besse, P., Lebrun, P., \& Chevalir, M. H. (1995). Hevea germplasm characterization using isozymes and RFLP Markers. In P. Baradat., W. T. Adam., \& G. Muller-Starck. (Eds.) Population Genetic and Genetic Conservation of forest trees (pp 129 134). Amsterdam, Netherlands: SPB Academic Publication.
Sequin, M., Rodier-Goud, M., \& Lespinase, D. (1997). Mapping SSR markers in rubber tree (Hevea brasiliensis) facilitated and enhanced by heteroduplex formation and templete mixing. Proceedings of Plant Animal Genome $V$ Conference (pp. 66). Washington, USA: USDA.

Setiyo, I. E. (2001). Pemetaan dan keragaman genetik RAPD pada kelapa sawit Sungei Pancur (RISPA) (Tesis). Institut Pertanian Bogor, Indonesia.

William, J. G. K., Kubelik, A. R., Lirak, K. J., Rafalsky, J. A., \& Tingey, S. V. (1990). DNA polymorphism amplified by arbitrary primers are useful as genetic markers. Nuleic Acids Res., 18(22), 6531-6535.

Woelan, S. (2013). Peta pautan genetik dan analisis QTL tanaman karet (Hevea brasiliensis Muell arg) pada populasi hasil persilangan RRIM 600 dengan PN 1546 sebagai dasar strategi peningkatan produksi lateks (Disertasi). Universitas Sumatera Utara, Indonesia.

Woelan, S., Sayurandi., \& Irwansyah, E. (2014). Keragaman genetik tanaman karet (Hevea braislinsis Muell Arg.) dari hasil persilangan interspesifik. Jurnal Penelitian Karet, 32(2), 109-121 